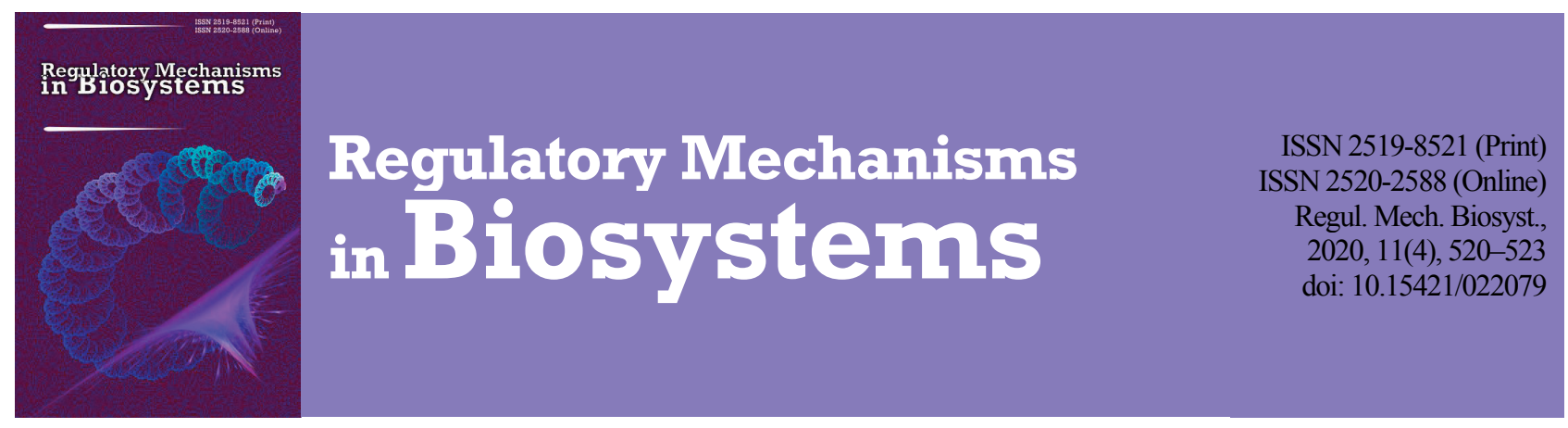

\title{
Complex impact of polarized and non-polarized low intense light and methylene blue on growth rate of some opportunistic microorganisms
}

\author{
V. V. Pantyo, G. M. Koval, E. M. Danko, V. I. Pantyo \\ Uzhhorod National University, Uzhhorod, Ukraine
}

Article info

Received 17.09.2020

Received in revised form 25.10.2020

Accepted 28.10 .2020

Uzhhorod National

University,

Pidhirna st., 46 ,

Uzhhorod, 88000, Ukraine.

Tel. +38-066-775-50-63.

E-mail:

valerij.pantyo@uzhnu.edu.ua

\begin{abstract}
Pantyo, V. V., Koval, G. M., Danko, E. M., \& Pantyo, V. I. (2020). Complex impact of polarized and non-polarized low intense light and methylene blue on growth rate of some opportunistic microorganisms. Regulatory Mechanisms in Biosystems, 11(4), 520-523. doi:10.15421/022079
\end{abstract}

Resistance to antibiotics is considered as a global and unsolved problem in the branch of medicine. That is why the use of novel non-drug methods of treatment of bacterial and fungal infections is of great relevance. One of such methods is photodynamic treatment, which is a treatment procedure that uses light energy to activate a photosensitizing agent in the presence of oxygen. Due to the broad spectrum of action, the efficacy against antibiotic resistant cells and the lack of selection of photoresistant strains, antimicrobial photodynamic therapy compares favourably with traditional drug therapy, and has emerged in the clinical field as a potential alternative to antibiotics to treat microbial infections. In this article results of studies of the complex effect of methylene blue $(0.1 \%$ aqueous solution) and LED radiation of the red-infrared spectrum as well as methylene blue and polarized incoherent low-energy radiation (PILER) with a red light filter on the growth rate of some opportunistic microorganisms on solid nutrient media are presented. Standardized suspensions of microorganisms were prepared for research with the subsequent determination of direct impact of polarized and non-polarized radiation (at duration of exposure of $5 \mathrm{~min}$ ), photosensitizer, and also the set of these factors on growth of the studied microorganisms. The growth intensity of bacteria and yeast-like fungi was determined by the number of their colonies after reseeding on nutrient media in Petri dishes. The obtained data were compared with control groups, which were not influenced by any factors. The results indicate a significant antimicrobial effect of the combined action of different types of radiation and methylene blue on microorganisms, which was manifested in a reduction in the number of colonies by on average $35-45 \%$, compared with the control groups. Comparing the effect of exposure when using LED and PILER light, we have noted its similarity. It is also worth noting a certain antimicrobial activity of $0.1 \%$ methylene blue solution on the studied strains, but this was much less pronounced than in the complex effect. The direct effect of both LED and PILER radiation with low duration of exposure caused the stimulation of the growth of the studied microorganisms with an increase in the number of their colonies on Petri dishes by $15-35 \%$. Given the rapid growth of resistance to antimicrobial agents, the described technique can be used as an alternative to traditional antibiotic therapy for the treatment of purulent-inflammatory diseases of the skin and mucous membranes.

Keywords: antimicrobial activity; LED radiation; PILER; photosensitizer; opportunistic microorganisms.

\section{Introduction}

The inevitable biological consequence of antibiotic therapy is the development of resistance of microorganisms, which requires the use of new generation drugs, stronger and more aggressive in relation to the human body (Melnychuk \& Lychkovska, 2015). This problem arose almost simultaneously with the discovery of the first antibiotics, but over the past few decades it has reached alarming socio-economic proportions (Bondar et al., 2016). Due to these, infections remain a major cause of death throughout the developing world (Kapoor et al., 2017).

The main ways to combat and overcome antibiotic resistance are prevention of transmission of resistant pathogens between patients, and rational antibiotic therapy (Svizhak \& Deyneka, 2014). However, it is important to search for new means to combat bacterial infections, among which a special place is occupied by both physical and chemical factors. These methods include phototherapy (Pantyo et al., 2017, 2018), antimicrobial photodynamic effects (Braun et al., 2008; Tavares et al., 2010; Kutsevlyak et al., 2014, 2015), ozone therapy (Melnychuk \& Lychkovska, 2015), development of novel chemical entities with new mechanisms of action (Slivka et al., 2017), use of essential oils (Kryvtsova et al., 2019), antibiotic adjuvants (González-Bello, 2017) etc. Advantages of physical methods are the reduction of the drug load on the human's body, preven- tion of allergic reactions and the absence of dysbiosis. In addition, nondrug methods of combating infectious agents can, if not replace, then limit the use of drugs, while affecting various parts of the pathological process, improving metabolic processes and activating the body's defense reactions (Melnychuk \& Lychkovska, 2015; Bondar et al., 2016).

Photodynamic therapy (PDT) is a modern and non-invasive form of therapy, used in the treatment of non-oncological diseases as well as cancers of various types and locations (Kwiatkowski et al., 2018). Antimicrobial PDT is based on the use of photosensitizers (PS) with the subsequent effect of low-intensity radiation of a certain wavelength, which triggers a photodynamic response (Kutsevlyak et al., 2014; Hamblin \& Jori, 2015; Boiko et al., 2017). In particular, methylene blue has three peaks of radiation absorption: in the ultraviolet $(200-320 \mathrm{~nm})$, green $(390-430 \mathrm{~nm})$ and red (530-700 nm) regions of the spectrum (Kutsevliak et al., 2015). Under the impact of light, the PS molecule goes into an excited state, and when it returns to the normal state, it transfers energy to other compounds. Most often, oxygen acts as an acceptor of this energy, which in turn triggers a cascade of free radical reactions, resulting in damage to biological structures. This in turn causes necrosis, or apoptosis of cells. PS has the ability to selectively accumulate in cells with energy deficiency, in particular tumour, damaged, or microbial cells (Kutsevlyak et al., 2014; Boiko et al., 2017; Kwiatkowski et al., 2018; Lan et al., 2019). 
Such excited and highly reactive state of oxygen is known as singlet oxygen. The latter is able to kill bacterial and fungal cells, as well as viral particles (Rajesh et al., 2011).

The main advantages of this method are: effectiveness against various pathogenic microorganisms (bacteria, fungi, viruses and protozoa); the impossibility of formation of resistant strains of bacteria, because the basis of photochemical processes are free radical reactions; painless, low invasiveness and almost complete absence of side effects; effectiveness in both acute and chronic diseases, as well as in some types of bacteriocarrier states; reducing the risk of complications in patients with general pathology; the possibility of repeating the procedure, as the effectiveness of PDT does not decrease with the next application; the possibility of the procedure in hard to reach places; selective activity of the method, so that the surrounding healthy tissues are not damaged; positive effect on nonspecific resistance of the organism; absence of toxic and mutagenic effects, etc. (Kutsevlyak et al., 2014; Boiko et al., 2017).

The aim of the work was to investigate and compare complex impact of LED radiation and $0.1 \%$ methylene blue solution as well as PILER light and methylene blue on the growth rate of some opportunistic microorganisms on solid nutrient media.

\section{Material and methods}

The combined effect of red-infrared LED radiation $(\lambda=640 \pm 30$ and $880 \pm 30$, power density from a distance of $0-1 \mathrm{~cm}-5.35 \mathrm{~mW} / \mathrm{cm}^{2}$ at continuous irradiation) and PILER (polarized incoherent low-energy radiation) light with red light filter $(\lambda \approx 630 \mathrm{~nm}$, power density on average $40 \mathrm{~mW} / \mathrm{cm}^{2}$ ) and $0.1 \%$ aqueous solution of methylene blue on the growth rate on solid nutrient media of clinical isolates of $S$. aureus, E. coli, C. albicans and collection test strains of S. aureus ATCC 25923, E. coli ATCC 25922 and C. albicans ATCC 90028 was performed at the microbiological laboratory of the Department of Microbiology, Virology, Epidemiology with the Course of Infectious Diseases of Uzhhorod National University. All clinical strains were isolated from the periodontal pocket in patients with chronic generalized periodontitis of II degree who were treated at the University Dental Clinic. For experimental study we have taken one clinical isolate of each species of microorganisms. Collection of clinical strains was carried out using sterile disposable tampons with subsequent delivery to the bacteriological laboratory in transport media. For primary identification of isolated microorganisms we used bacterioscopical and bacteriological methods using universal and diagnostic chromogenic nutrient media (UriSelectTM 4 Medium). For final identification biochemical methods were performed using test systems Staphytest 16, Enterotest 16, and Candidatest 21 by Erba Lachema.

For experimental studies, 16-24 hour agar cultures of microorganisms were used, which were brought to a turbidity standard of 0.5 according to McFarland, after which they were additionally diluted 160 thousand fold. All studied microorganisms were divided into four groups. The first, control, group included standardized in a liquid nutrient medium microorganisms, which in a volume of $0.1 \mathrm{~mL}$ were subcultured on solid nutrient media (MPA or Endo for bacteria and Saburo for fungi of the genus Candida) to determine the number of colonies after 24 hours of incubation at $37^{\circ} \mathrm{C}$. Standardized suspensions of microorganisms of the second group were irradiated with LED and PILER light with the duration of exposure $5 \mathrm{~min}$. Studies of the effect of different types of radiation on the growth of the microbial suspension were performed in separate series. Irradiation with LED radiation was carried out immediately after the inoculation of a standardized inoculum in Petri dishes with a nutrient medium. Irradiation of the inoculum with PILER with a red light filter was performed in sterile Petri dishes with a diameter of $50 \mathrm{~mm}$ from a distance of $50 \mathrm{~mm}$, followed by reseeding on nutrient media. The volume of irradiated inoculum was $1 \mathrm{~mL}$. After irradiation, microbial inoculum in volume $0.1 \mathrm{~mL}$ was reseeded in the Petri dishes with solid nutrient media.

To a standardized suspension of microorganisms of the third group $0.1 \%$ methylene blue solution was added in a ratio of $1: 10$, kept for $30 \mathrm{~min}$ in a thermostat and reseeded on solid nutrient media. Microorganisms of the 4th group after the addition of $0.1 \%$ methylene blue were irradiated with LED and PILER radiation. Irradiation of the inoculum with a solution of $0.1 \%$ methylene blue was carried out similarly to micro- organisms of the second group. The interval between the application of photosensitizer and irradiation was 30 minutes. During this time, the suspensions of microorganisms with a photosensitizer were kept in a thermostat. The growth rate of microorganisms was determined by counting the number of colonies on the Petri dishes after 24 hours of cultivation at $37^{\circ} \mathrm{C}$. All studies were performed in 5 replicates.

Thus, one series of experiments included studies of the direct effect on the growth rate of the investigated microorganisms of the following factors: radiation (experimental group II); photosensitizer methylene blue (experimental group III); combined exposure of photosensitizer and radiation (experimental group IV). After cultivation in thermostat, number of colonies of each experimental group was compared with the control (group I).

It should be noted that the experimental groups of microorganisms were formed, according to similar studies of the antimicrobial photodynamic activity of various photosensitizers (Rolim et al., 2012; Kutsevlyak et al., 2014; Boiko et al., 2017). At the same time, this technique was significantly improved, in particular the standardization of the microbial inoculum with the possibility of conducting a series of reproducible and statistically significant quantitative studies.

The source of LED radiation was a Medolight-Red device by Bioptron light therapy system by Zepter Group. The source of PILER radiation was the Bioptron Med All device by the Bioptron light therapy system by Zepter Group. Irradiation of the microbial inoculum was carried out in a room without windows in complete darkness to prevent the ingress of extraneous light. Data were statistically processed to determine the arithmetic mean $(\mathrm{x})$ and standard deviation (SD) of the sample using Statistica 10.0 (StatSoft Inc., USA).

\section{Results}

The combination of $0.1 \%$ solution of methylene blue and LED radiation of the red-infrared range and PILER light with a red light filter had a bactericidal and fungicidal effect on the studied strains of microorganisms. Table 1 shows the quantitative data on the growth of microorganisms of all four groups on nutrient media using LED radiation.

\section{Table 1}

Number of colonies of the studied groups of microorganisms on solid nutrient media using LED radiation $(\mathrm{x} \pm \mathrm{SD} ; \mathrm{n}=5)$

\begin{tabular}{lcccc}
\hline \multicolumn{1}{c}{$\begin{array}{c}\text { Species of } \\
\text { microorganisms }\end{array}$} & $\begin{array}{c}\text { I group } \\
\text { (control) }\end{array}$ & $\begin{array}{c}\text { II group (irradia- } \\
\text { tion with LED } \\
\text { radiation) }\end{array}$ & $\begin{array}{c}\text { III group } \\
\text { (adding a } \\
\text { photosensitizer) }\end{array}$ & $\begin{array}{c}\text { IV group } \\
\text { (photosensitizer } \\
\text { + irradiation) }\end{array}$ \\
\hline $\begin{array}{l}\text { S. aureus } \\
\text { (clinical isolate) }\end{array}$ & $44.8 \pm 4.3$ & $56.4 \pm 3.6$ & $36.8 \pm 4.0$ & $26.6 \pm 3.4$ \\
$\begin{array}{l}\text { S. aureus } \\
\text { ATCC 25923 }\end{array}$ & $60.0 \pm 4.9$ & $69.6 \pm 3.2$ & $48.6 \pm 2.9$ & $39.4 \pm 3.4$ \\
$\begin{array}{l}\text { E. coli } \\
\text { (clinical isolate) }\end{array}$ & $34.4 \pm 4.3$ & $46.4 \pm 5.3$ & $28.6 \pm 5.4$ & $22.0 \pm 4.4$ \\
$\begin{array}{l}\text { E. coli } \\
\text { ATCC 25922 }\end{array}$ & $43.8 \pm 4.1$ & $54.0 \pm 3.4$ & $33.8 \pm 3.1$ & $26.2 \pm 3.0$ \\
$\begin{array}{l}\text { C. albicans } \\
\text { (clinical isolate) }\end{array}$ & $31.4 \pm 4.6$ & $37.8 \pm 5.2$ & $26.6 \pm 4.0$ & $20.6 \pm 2.9$ \\
$\begin{array}{l}\text { C. albicans } \\
\text { ATCC 90028 }\end{array}$ & $25.6 \pm 4.8$ & $30.4 \pm 3.2$ & $20.8 \pm 5.1$ & $16.0 \pm 4.7$ \\
\hline
\end{tabular}

Irradiation of the studied microorganisms with LED radiation of the red-infrared range with exposure duration of $5 \mathrm{~min}$ (group II) caused an increase in the number of their colonies on the Petri dishes. In particular, the number of microbial colonies after irradiation increased by $16-35 \%$, comparing with the group I. Adding $0.1 \%$ solution of methylene blue (group III) caused decrease in the growth rate of the microflora by 16$23 \%$ compared with the control. The most pronounced antimicrobial effect was observed in the group IV, when combined with methylene blue and LED radiation. The number of colonies on Petri dishes decreased by $35-41 \%$ compared with the control. The highest antimicrobial effect was observed in relation to the clinical isolate of $S$. aureus and the collection strain of $E$. coli ATCC 25922.

Table 2 shows quantitative data on the growth of microorganisms in all four groups on nutrient media using PILER light. When using PILER light, similar patterns were observed compared to LED radiation. Thus, 
the number of colonies of microorganisms of the second group on Petri dishes was higher on average by $15-33 \%$ compared with the control, and the highest stimulating effect of radiation was observed in relation to the studied strains of $C$. albicans. The addition of a photosensitizer inhibited the growth of the studied microorganisms of the third group by $18-23 \%$, compared with the microorganisms of the first group. The photodynamic effect of $0.1 \%$ solution of methylene blue and 5-minute application of PILER light with a red filter reduced the growth rate of microorganisms by $35-45 \%$ compared with the control.

\section{Table 2}

Number of colonies of the studied groups of microorganisms on solid nutrient media using PILER light $(\mathrm{x} \pm \mathrm{SD} ; \mathrm{n}=5)$

\begin{tabular}{lcccc}
\hline \multicolumn{1}{c}{$\begin{array}{c}\text { Species of } \\
\text { microorganisms }\end{array}$} & $\begin{array}{c}\text { I group } \\
\text { (control) }\end{array}$ & $\begin{array}{c}\text { II group (irradia- } \\
\text { tion with } \\
\text { PILER light) }\end{array}$ & $\begin{array}{c}\text { III group } \\
\text { (adding a } \\
\text { photosensitizer) }\end{array}$ & $\begin{array}{c}\text { IV group } \\
\text { (photosensitizer } \\
\text { +irradiation) }\end{array}$ \\
\hline $\begin{array}{l}\text { S. aureus } \\
\text { (clinical isolate) }\end{array}$ & $53.2 \pm 6.9$ & $61.8 \pm 4.7$ & $41.4 \pm 3.9$ & $32.8 \pm 5.6$ \\
$\begin{array}{l}\text { S. aureus } \\
\text { ATCC 25923 }\end{array}$ & $66.2 \pm 6.3$ & $76.0 \pm 6.3$ & $51.4 \pm 5.1$ & $39.0 \pm 5.3$ \\
$\begin{array}{l}\text { E. coli } \\
\text { (clinical isolate) }\end{array}$ & $69.4 \pm 9.2$ & $82.6 \pm 10.3$ & $55.2 \pm 6.6$ & $42.4 \pm 5.8$ \\
$\begin{array}{l}\text { E. coli } \\
\text { ATCC 25922 }\end{array}$ & $65.2 \pm 6.5$ & $77.2 \pm 7.0$ & $53.4 \pm 5.2$ & $42.4 \pm 4.8$ \\
$\begin{array}{l}\text { C. albicans } \\
\text { (clinical isolate) }\end{array}$ & $36.4 \pm 4.4$ & $44.4 \pm 5.6$ & $28.0 \pm 2.6$ & $20.0 \pm 3.6$ \\
$\begin{array}{l}\text { C. albicans } \\
\text { ATCC 90028 }\end{array}$ & $30.8 \pm 3.9$ & $38.0 \pm 4.2$ & $24.2 \pm 3.5$ & $16.8 \pm 3.0$ \\
\hline
\end{tabular}

\section{Discussion}

The results showed that short-term $(5 \mathrm{~min})$ exposure to both LED and PILER radiation had a stimulating effect on the studied microorganisms, which was manifested by an increase in the growth rate of colonies of microorganisms by $15-35 \%$, compared with the control group, which was not affected either by radiation, nor a photosensitizer. It should be noted that, according to previous studies (Pantyo et al., 2017, 2018), with increasing dose density (i.e. duration) of radiation a quite pronounced antimicrobial effect of these types of radiation was observed against investigated opportunistic pathogens.

The direct action of $0.1 \%$ methylene blue solution showed moderate antimicrobial activity, which was manifested in a decrease in the number of microbial colonies on solid nutrient media by $16-23 \%$. However, the most significant antimicrobial effect was achieved with the combined action of the photosensitizer methylene blue and low-intensity radiation of the red spectrum. On average, the growth rate of microorganisms of the group 4 decreased by $35-45 \%$, compared with the first (control) group.

Comparing results of our studies and results of similar investigations of antimicrobial PDT (Kutsevliak et al., 2014; Boiko et al., 2017), we can note that they are corresponding. But, at the same time, data of our investigations of the growth rate of investigated strains of microorganisms after impact of different factors (PILER and LED radiation; PS and set of these factors) are both qualitative and quantitative. The significant antimicrobial effect of PDT in the low concentration of PS $(0.1 \%$ aqueous solution of methylene blue was additionally diluted 10 fold in microbial inoculum) could be promising for wide use of our method in medical and dental practice. This, in turn, will help reduce the side effects of PDT.

It also should be noted that agreeably with results of experimental studies, photosensitizers with distinct characteristics result in variable activity in cells (Rolim et al., 2012; Lan et al., 2019). In our research we observed complex effect of different types of radiation (polarized and non-polarized), but with almost the same wavelength and one PS (methylene blue solution) on the growth rate of certain opportunistic microorganisms. Comparing the results, obtained using LED radiation of the red-infrared spectrum and PILER light with a red light filter, their similarity should be noted, as should the stimulating effect of different types of radiation on microorganisms of the second group was analogous.

The above suggests that the determining factors of the biological action of radiation on microbial cells are its wavelength and power density, because at similar parameters of these indicators the obtained results were similar. In this case, such a parameter as polarization, in our opinion, did not play a significant role in the biological effect of low-intensity radiation.

According to the data of Ukrainian and foreign scientists, antimicrobial PDT can be successfully used in treatment of marginal periodontitis (Braun et al., 2008), apical periodontitis (Garcez et al., 2007), peri-implantitis (Rajesh et al., 2012), localized infectious processes (Huang et al., 2010), inflammatory diseases of the tracheobronchial tree (Boiko et al., 2017) etc. Besides, PDT can be applied in treatment of infections, caused by antibiotic resistant strains of microorganisms (Fu et al., 2013). Another benefit of using PDT in treatment of infections, caused by gram-negative bacteria is inactivation of endotoxins (Rajesh et al., 2012).

\section{Conclusions}

The combined effect of $0.1 \%$ aqueous solution of methylene blue and polarized (PILER) and non-polarized (LED) radiation has a pronounced antimicrobial effect against the studied gram-positive and gram-negative opportunistic pathogens, as well as yeast-like fungi Candida albicans. With the stimulating effect of low-intensity short-term radiation exposure and relatively insignificant antimicrobial effect of methylene blue solution on the studied microorganisms, the complex use of these two factors reduces the growth rate of microorganisms on solid media by on average 35$45 \%$ compared with the control group. Given the significant rate of occurrence and spread of antibiotic resistance, the use of the proposed technique may be appropriate in the treatment of, in particular, pathology of periodontal tissues and purulent-inflammatory diseases of the superficial localization. Perspectives of further research include investigation of the complex impact of other photosensitizers and low-energy radiation on biological properties of planktonic and biofilm forms of microorganisms. In the future, the results obtained can be used in the treatment of pathological processes of periodontal tissues, as well as purulent-inflammatory infections of the skin and mucous membranes.

\section{References}

Boiko, V. V., Krasnoiaruzhskyi, A. G., \& Kritsak, V. V. (2017). Vybor fotosensibilizatora i parametrov svetovogo izlucheniya dlya provedeniya endoskopicheskoj endobronkhial'noj fotodinamicheskoj terapii [The choice of photosensitizer and light parameters for endobronchial endoscopic photodynamic therapy]. International Medical Journal, 23(2), 28-32 (in Russian).

Bondar, M. V., Pylypenko, M. M., Svintukovskyi, M. Y., Kharchenko, L. A., Prevysla, O. M., \& Tsvyk, I. M. (2016). Antybiotykorezystentnist' mikroorhanizmiv: Mekhanizmy rozvytku y shliakhy zapobihannia [Antibiotic resistance: Mechanisms of development and ways to prevent them]. Emergency Medicine, 74(3), 11-17 (in Ukrainian).

Braun, A., Dehn, C., Krause, F., \& Jepsen, S. (2008). Short-term clinical effects of adjunctive antimicrobial photodynamic therapy in periodontal treatment: A randomized clinical trial. Journal of Clinical Periodontology, 35(10), 877-884.

Fu, X. J., Fang, Y., \& Yao, M. (2013). Antimicrobial photodynamic therapy for methicillin-resistant Staphylococcus aureus infection. BioMed Research International, 2013, 159157.

Garcez, A. S., Ribeiro, M. S., Tegos, G. P., Núñez, S. C., Jorge, A. O., \& Hamblin, M. R. (2007). Antimicrobial photodynamic therapy combined with conventionnal endodontic treatment to eliminate root canal biofilm infection. Lasers in Surgery and Medicine, 39(1), 59-66.

Gonzalez-Bello, C. (2017). Antibiotic adjuvants - a strategy to unlock bacterial resistance to antibiotics. Bioorganic and Medicinal Chemistry Letters, 27(18), 42214228.

Hamblin, M. R., \& Jori, G. (Eds.). (2015). Photodynamic inactivation of microbial pathogens: Medical and environmental applications. Royal Society of Chemistry.

Huang, L., Dai, T., \& Hamblin, M. R. (2010). Antimicrobial photodynamic inactivation and photodynamic therapy for infections. In: Photodynamic Therapy. Humana Press, Totowa. Pp. 155-173.

Kapoor, G., Saigal, S., \& Elongavan, A. (2017). Action and resistance mechanisms of antibiotics: A guide for clinicians. Journal of Anaesthesiology, Clinical Pharmacology, 33(3), 300-305.

Kryvtsova, M. V., Salamon, I., Koscova, J., Bucko, D., \& Spivak, M. (2019). Antimicrobial, antibiofilm and biochemichal properties of Thymus vulgaris essential oil against clinical isolates of opportunistic infections. Biosystems Diversity, 27(3), 270-275.

Kutsevliak, V. F., Bozhko, K. V., Poliakova, S. V., Severin, L. V., Kashura, Y. A., Biriukova, S. V., Voyda, Y. V., Korobov, A. M., \& Ponomariov, G. V. (2015). 
Antibakterial'naya aktivnost' fotodinamicheskogo vozdejstviya in vitro na standartnuyu kul'turu Candida albicans [Antibacterial activity of photodynamic effect in vitro on Candida albicans in standard culture]. Photobiology and Photomedicine, 12, 66-73 (in Russian).

Kutsevlyak, V. F., Pushkar, L. Y., Severin, L. V., Veligorya, I. E., Voida, Y. V., Biryukova, S. V., Korobov, A. M., \& Ponomarev, G. V. (2014). Antibakterial'naya aktivnost' fotodinamicheskoj terapii s primeneniem razlichny'kh fotosensibilizatorov (issledovanie in vitro) [Antibacterial activity of photodynamic therapy using various photosensitizers (study in vitro)]. Photobiology and Photomedicine, 12, 78-85 (in Russian).

Kwiatkowski, S., Knap, B., Przystupski, D., Saczko, J., Kędzierska, E., Knap-Czop, K, \& Kulbacka, J. (2018). Photodynamic therapy - mechanisms, photosensitizers and combinations. Biomedicine and Pharmacotherapy, 106, 1098-1107.

Lan, M., Zhao, S., Liu, W., Lee, C. S., Zhang, W., \& Wang, P. (2019). Photosensitizers for photodynamic therapy. Advanced Healthcare Materials, 8(13), 1900132.

Melnychuk, H. M., \& Lychkovska, O. L. (2015). Alternatyvni nemedykamentozni metody protymikrobnoho likuvannia khvorykh iz patolohiieiu parodonta: Ozonoterapiia, fotodynamoterapiia; mekhanizm diji, pokazannia ta protypokazannia do vykorystannia [Alternative non-drug methods of the antimicrobial treatment of parodontium diseases: Ozone therapy and photodynamic therapy; the mechanism of action, indication and contraindication to use]. Clinical Dentistry, 1 , 28-37 (in Ukrainian).

Pantyo, V. V., Koval, G. M., Pantyo, V. I., \& Gulyar, S. O. (2017). Vplyv svitlodiodnoho vyprominiuvannia riznykh dovzhyn khvyl na intensyvnist rostu Staphylococcus aureus [Influence of led radiation of various wave length on growth in- tensity of Staphylococcus aureus]. Science Rise: Biological Science, 7(4), 16 20 (in Ukrainian)

Pantyo, V. V., Pantyo, V. I., \& Danko, E. M. (2018). Vplyv PILER-vyprominiuvannia na intensyvnist' rostu umovno-patohennykh mikroorhanizmiv [The impact of PILER-radiation on the growth rate of opportunistic microorganisms]. Reports of Vinnytsia National Medical University, 22(2), 272-276 (in Ukrainian).

Rajesh, S., Koshi, E., Philip, K., \& Mohan, A. (2011). Antimicrobial photodynamic therapy: An overview. Journal of Indian Society of Periodontology, 15(4), 323-327.

Rolim, J. P., De-Melo, M. A., Guedes, S. F., Albuquerque-Filho, F. B., De Souza, J. R., Nogueira, N. A., Zanin, C. J., \& Rodrigues, L. K. (2012). The antimicrobial activity of photodynamic therapy against Streptococcus mutans using different photosensitizers. Journal of Photochemistry and Photobiology B: Biology, $106,40-46$.

Slivka, M., Korol, N., Pantyo, V., Baumer, V., \& Lendel, V. (2017). Regio-and stereoselective synthesis of [1,3] thiazolo[3,2-b][1,2,4]triazol-7-ium salts via electrophilic heterocyclization of 3-S-propargylthio-4H-1,2,4-triazoles and their antimicrobial activity. Heterocyclic Communications, 23(2), 109-113.

Svizhak, V. K., \& Deyneka, S. E. (2014). Antybiotykorezystentnist: Bahatohrannist' problemy [Antibiotic resistance: Many-sided nature of the problem]. Clinical and Experimental Pathology, 13(2), 222-224 (in Ukrainian).

Tavares, A., Carvalho, C. M. B., Faustino, M. A., Neves, M. G. P. M. S., Tome, J. P. C., Tome, A. C., Cavaleiro, J. A. S., Cunha, A., Gomes, N. C. M., Alves, E., \& Almeida, A. (2010). Antimicrobial photodynamic therapy: Study of bacterial recovery viability and potential development of resistance after treatment. Marine Drugs, 8(1), 91-105. 